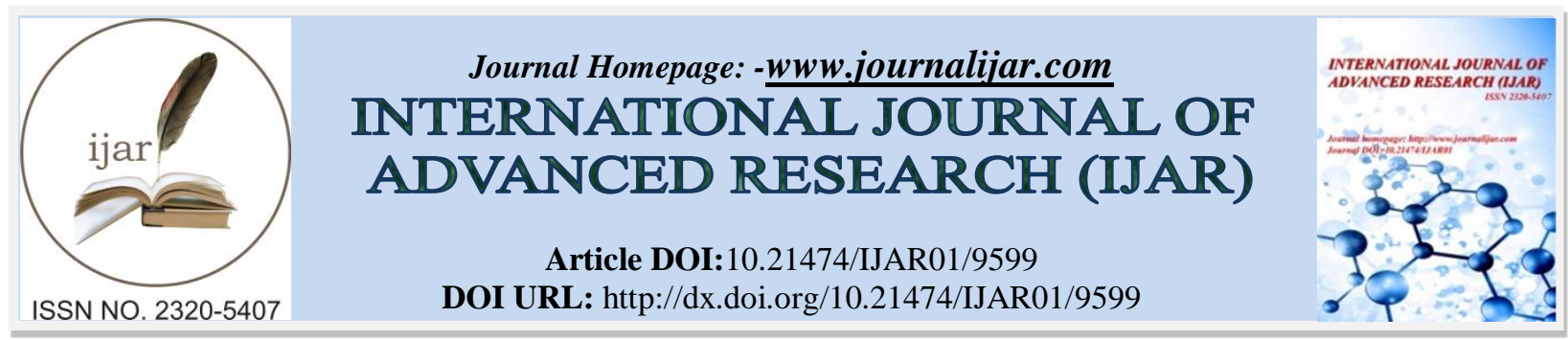

RESEARCH ARTICLE

\title{
A IMPEDIMENT OF INSURANCE SERVICES IN MANIPUR.
}

\author{
Dr. Nongmaithem Kamala Devi.
}

\section{Manuscript Info}

Manuscript History

Received: 20 June 2019

Final Accepted: 22 July 2019

Published: August 2019

\begin{abstract}
In India after deregulation of insurance sector, there was a large change in insurance business, their products and services offered to the clients. This insurance sector also plays a remarkable role in the advancement of a country's economy. From many previous study shows that insurance spread is extremely thin in India. Though, many research studies has not attempted to expose the reason why the insurance services were not purchasing or used by the local people especially the unreached areas. This paper will inquire about to fill up this gap. Therefore, this study provides a brief analysis of obstacles faced by the insurance services providers in terms of before opening an insurance branch to unreached areas and their services delivery to the clients in Manipur. This study also has identified the dependable factors for escalating the cost of penetration to unreached areas.
\end{abstract}

Copy Right, IJAR, 2019,. All rights reserved.

\section{Introduction:-}

India has the maximum number of policies for life insurances and large volume employees run more than 2000 branch offices of the Life Insurance Corporation of India. Non-life insurance also offers security against property damage, accidents and other liabilities. The extend of insurance services is very thin in India (Ranade, A., \& Ahuja, R., 1999). However, from the Cummins \& Doherty (2006) paper tells that the decision of buying any insurance policies depend of the value of the insurer's promise, way of settling claim and their financial capability.

\section{Literature Review:-}

The actual consumption of insurance products will give many benefits to clients. However, studies about South Asia Country wise exclusion of insurance reveals that about ninety percent of the populations are excluded from Insurance in India according to Marc (2005).

Khaur (2005) highlighted that like other Asian countries, the purchasing of insurance by Indian people is very low. And the main reason for falling down of insurance density in India is country's high population growth rate. This study suggested that the condition of insurance services can be improved if they give more emphasis on awareness of the need for protection and retirement planning to the people.

From the report of UNDP (2007) also illustrate that great numbers of poor India are excluded from formal market of insurance. Among the five million people outreach of micro insurance, only two percent of the country poor is covering. So, there is a high chance to expand micro insurance services in the country if the service providers spread the awareness and their benefits to the people.

Corresponding Author:-Dr. Nongmaithem Kamala Devi. 
Mukherjee (2010) study revealed that a bulk of the unorganized workers still left out from insurance service even though their density was achieved ninety percent of the Indian workforce in 2008 . Therefore, the providers are looking for government subsidies and donor.

Furthermore the LIC of India has paying more attention on savings-linked to micro insurance policies and over term products. They can easily control the individual micro insurance policies transaction costs and also through the linked of small MFIs, they sells group credit-life micro-insurance to people (Mukherjee, 2012).

And the awareness and confidence level of the customers has increased tremendously as the insurance market in India has grown five times over the past ten years. And India stands the fifth most attractive target place for real estate investment in FICCI report. So, the country has a lot of opportunities for investment in near future (Purusothaman, 2013).

According to Kumabam et al. (2013) elucidate the buying behavior of the health insurance product by the society of Manipur. This article also mentions that majority of the respondent who are aware of the policy of health insurance does not own an insurance policy. Hence, the stakeholders of Insurance play a vital role in the outreach of health insurance.

\section{Objective of the Study:-}

1. To understand the factors hindered in the delivery of Insurance services in Manipur.

2. To know the insurance services dependable factors for escalating the cost of penetration to unreached areas of Manipur.

\section{Research Methodology:-}

Out of eighteen branches of Insurance companies exist in the state, sixteen branches has been responded. So, sixteen branches were chosen for this study. The primary data was collected through survey questionnaires and informal discussion by asking the opinion of the branch manager towards their obstacles faced when they try to deliver services to people. The researcher asked the officials to rank all the factors of the corresponding questions in order. The ranks assigned by the officials were transformed into score with the help of Henry Garrett Ranking Method. For this, first calculated percent position of each rank:

Where,

$$
\text { Percent Position }=100(\text { Rij }-0.5) / \mathrm{Nj}
$$

Rij= Rank given for the ith variable by the jth respondents (officials)

$\mathrm{Nj}=$ Number of variable ranked by jth respondents

Then, the estimated percent positions were transformed into Garrett Value by using Garrett's conversion table. Finally, the researcher has calculated each factors total score value and average mean score. Among the average mean scores, having highest value factor shows the most challenging factor and rank as first rank, followed by second highest score value as second rank and so on.

\section{Result and Analysis of the Study:-}

\section{Survey Performance for Opening New Insurance Branches}

Performing a survey can easily aware of any situational difficulties and their possible clarification. Fig. 1 below shows the facts related to Insurance companies that whether they conducted an informal survey prior to opening any new branch. This study gives an idea that most of the institutional higher official likes to do informal survey either for most branches (thirty one percent) or all branches (twenty five percent) because opening a new branch in unfamiliar region involved lot of risk and cost. However, six percent of the official responds that they performed survey for some branches only. 
Figure 1:- Survey Performance for Opening New Insurance Branches

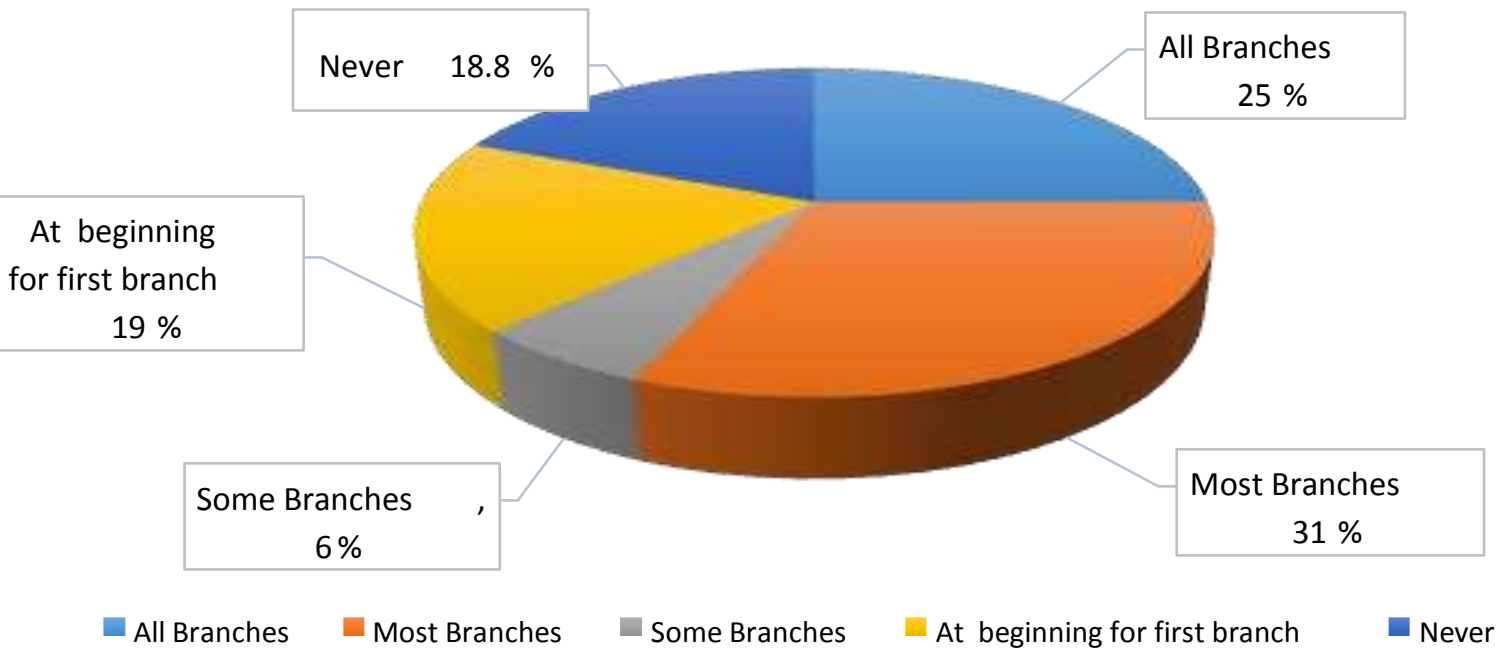

Most Considered Factors for Opening a Insurance Branch -Garrett Ranking

As of the informal discussion with the insurance officials and their opinion in survey reveals that the companies were considered some basic criteria for opening a branch. The table 1 below gives evidence that the' region population size' is the first most important factor when the institution looks for a place to open a new branch. The 'quantum business' of the place was the second most practical factor looking by the insurance institutions. The third most considered factor was the necessity of the 'higher official order and direction'. Then the next considered factors were transportation infrastructure and safety of branch and staff. However, the factor 'main concern to unreached region' has the last rank which means the insurance institutional does not gives much importance to unreached area first.

Table 1:-Most Considered Factors for Opening a Insurance Branch -Garrett Ranking

\begin{tabular}{|c|c|c|c|c|c|c|c|c|c|c|c|}
\hline \multirow[t]{2}{*}{ Factors } & \multicolumn{8}{|c|}{ Rank given by the officials } & \multirow[b]{2}{*}{$\begin{array}{l}\text { Total } \\
\text { Garrett } \\
\text { Value } \\
\end{array}$} & \multirow[b]{2}{*}{$\begin{array}{l}\text { Avera } \\
\text { ge } \\
\text { Score }\end{array}$} & \multirow[b]{2}{*}{$\begin{array}{l}\operatorname{Ran} \\
\mathrm{k}\end{array}$} \\
\hline & 1 & 2 & 3 & 4 & 5 & 6 & 7 & 8 & & & \\
\hline Region Population Size & $\begin{array}{l}64 \\
0\end{array}$ & $\begin{array}{ll}54 \\
4\end{array}$ & 0 & 0 & 0 & 0 & 0 & 0 & 1184 & 74 & 1 \\
\hline Transportation Infrastructure & 0 & 0 & $\begin{array}{l}30 \\
0\end{array}$ & $\begin{array}{l}37 \\
1\end{array}$ & $\begin{array}{l}18 \\
8\end{array}$ & 0 & 0 & 0 & 859 & 53.68 & 4 \\
\hline Quantum Business & $\begin{array}{l}56 \\
0\end{array}$ & $\begin{array}{l}34 \\
0\end{array}$ & $\begin{array}{l}18 \\
0\end{array}$ & 53 & 0 & 0 & 0 & 0 & 1133 & 70.81 & 2 \\
\hline Higher Official Order and Direction & 0 & $\begin{array}{l}13 \\
6\end{array}$ & $\begin{array}{l}36 \\
0\end{array}$ & $\begin{array}{l}26 \\
5\end{array}$ & 47 & 80 & 0 & 0 & 888 & 55.5 & 3 \\
\hline Local People Request & 0 & 0 & 0 & 0 & 0 & 0 & $\begin{array}{l}19 \\
8\end{array}$ & $\begin{array}{l}20 \\
0\end{array}$ & 398 & 24.87 & 8 \\
\hline Main Concern to Unreached Region & 0 & 0 & 0 & 53 & 47 & 40 & $\begin{array}{l}23 \\
1\end{array}$ & $\begin{array}{l}12 \\
0\end{array}$ & 491 & 30.68 & 7 \\
\hline $\begin{array}{l}\text { Give first priority to safety of branch } \\
\text { and staff }\end{array}$ & 80 & 68 & 60 & 53 & $\begin{array}{l}37 \\
6 \\
\end{array}$ & $\begin{array}{l}16 \\
0\end{array}$ & 0 & 0 & 797 & 49.81 & 5 \\
\hline Free from extortion threats Area First & 0 & 0 & 60 & 53 & 94 & $\begin{array}{l}36 \\
0\end{array}$ & 99 & 0 & 666 & 41.62 & 6 \\
\hline
\end{tabular}




\section{Delivery of Insurance Service - Garrett Ranking}

The table 2 shows the Garrett value and ranking to identify the most challenging factor that hindered the delivery of Insurance services in Manipur. The customer behavior and attitude towards insurance products was the main key reason for waning the delivery of services. The second reason is the socio economic condition of the client. The next impeding factor was the geographic physical infrastructure (road condition and connectivity, communication network etc.). As the institutional operational efficiency (customer query, hiring and retaining employees, employees' technical skills and knowledge) and Information Technology factors were in last ranks confirmed that they are not the main factor which hindered the delivery of insurance to the state. And from the informal discussion with some of the insurance providers' officials also tell that the state income level may be the possible root cause for hindering the delivery or no usage of insurance products. They also clarify that the agents of corresponding services providers encourage a lot of clients including potential individual to use the services by meeting them personally. From that, most of the potential client was not very interest in insurance services at all. Very few were showing interest to them.

Table 2:- Factors Hindered the Delivery of Insurance Service - Garrett Ranking

\begin{tabular}{|c|c|c|c|c|c|c|c|c|c|}
\hline \multirow[t]{2}{*}{ Factors } & \multicolumn{6}{|c|}{ Rank given by the Officials } & \multirow[b]{2}{*}{$\begin{array}{l}\text { Total } \\
\text { Value }\end{array}$} & \multirow[b]{2}{*}{$\begin{array}{l}\text { Average } \\
\text { Score }\end{array}$} & \multirow[b]{2}{*}{$\begin{array}{l}\text { Ran } \\
\mathrm{k}\end{array}$} \\
\hline & $1^{\mathrm{st}}$ & $2^{\text {nd }}$ & $3^{\text {rd }}$ & $4^{\text {th }}$ & $5^{\text {th }}$ & $6^{\text {th }}$ & & & \\
\hline $\begin{array}{lll}\text { F1- Customer } & \text { Attitude } & \text { and } \\
\text { Awareness } & & \\
\end{array}$ & $\begin{array}{l}69 \\
3\end{array}$ & $\begin{array}{l}25 \\
2\end{array}$ & $\begin{array}{l}16 \\
2\end{array}$ & 0 & 0 & 0 & 1107 & 69.1875 & 1 \\
\hline $\begin{array}{l}\text { F2- Institutional Infrastructure } \\
\text { Availability }\end{array}$ & 0 & 63 & $\begin{array}{l}16 \\
2\end{array}$ & $\begin{array}{l}23 \\
0\end{array}$ & $\begin{array}{l}22 \\
2\end{array}$ & 23 & 700 & 43.75 & 4 \\
\hline $\begin{array}{l}\text { F3- Institutional Operational } \\
\text { Efficiency }\end{array}$ & 0 & 0 & $\begin{array}{l}10 \\
8\end{array}$ & $\begin{array}{l}23 \\
0\end{array}$ & $\begin{array}{l}25 \\
9\end{array}$ & 46 & 643 & 40.1875 & 5 \\
\hline $\begin{array}{l}\text { F4- Geographic } \quad \text { Physical } \\
\text { Infrastructure }\end{array}$ & $\begin{array}{l}15 \\
4\end{array}$ & $\begin{array}{l}18 \\
9\end{array}$ & $\begin{array}{l}32 \\
4\end{array}$ & $\begin{array}{l}18 \\
4\end{array}$ & 37 & 0 & 888 & 55.5 & 3 \\
\hline F5- Socio Economic & $\begin{array}{l}38 \\
5\end{array}$ & $\begin{array}{l}50 \\
4\end{array}$ & 0 & 46 & 74 & 0 & 1009 & 63.0625 & 2 \\
\hline F6- Update Modern Technology & 0 & 0 & $\begin{array}{l}10 \\
8\end{array}$ & 46 & 37 & $\begin{array}{l}27 \\
6\end{array}$ & 467 & 29.1875 & 6 \\
\hline
\end{tabular}

Insurance Services Dependable Cost Factors for Penetration - Garrett Ranking

Table 3:-Insurance Services Dependable Cost Factors for Penetration - Garrett Ranking

\begin{tabular}{|c|c|c|c|c|c|c|c|c|c|c|}
\hline \multirow[b]{2}{*}{ Variables } & \multicolumn{7}{|c|}{ Rank given by the officials } & \multirow{2}{*}{$\begin{array}{l}\text { Tota } \\
1 \\
\text { Garr } \\
\text { ett } \\
\text { Val } \\
\text { ue }\end{array}$} & \multirow[b]{2}{*}{$\begin{array}{l}\text { Aver } \\
\text { age } \\
\text { Valu } \\
\text { e }\end{array}$} & \multirow[b]{2}{*}{$\begin{array}{l}\mathrm{Ra} \\
\mathrm{nk}\end{array}$} \\
\hline & 1 & 2 & 3 & 4 & 5 & 6 & 7 & & & \\
\hline High one-time payment cost for premises of a branch & $\begin{array}{l}7 \\
8 \\
0\end{array}$ & $\begin{array}{l}2 \\
6 \\
4\end{array}$ & 0 & $\begin{array}{l}5 \\
0\end{array}$ & 0 & 0 & 0 & $\begin{array}{l}109 \\
4\end{array}$ & $\begin{array}{l}68.3 \\
7\end{array}$ & 2 \\
\hline High fixed asset, furniture \& fixture cost & 0 & $\begin{array}{l}6 \\
6\end{array}$ & $\begin{array}{l}3 \\
4 \\
8\end{array}$ & $\begin{array}{l}2 \\
0 \\
0\end{array}$ & $\begin{array}{l}1 \\
2 \\
9\end{array}$ & $\begin{array}{l}6 \\
8\end{array}$ & 0 & 811 & $\begin{array}{l}50.6 \\
8\end{array}$ & 3 \\
\hline $\begin{array}{l}\text { High cost involved in electricity, stationary items, } \\
\text { transportation and communication }\end{array}$ & 0 & 0 & $\begin{array}{l}1 \\
1 \\
6\end{array}$ & 0 & $\begin{array}{l}8 \\
6\end{array}$ & $\begin{array}{l}2 \\
0 \\
4\end{array}$ & 126 & 532 & $\begin{array}{l}33.2 \\
5\end{array}$ & 6 \\
\hline The cost of employment of staff is very high & 0 & $\begin{array}{l}6 \\
6\end{array}$ & $\begin{array}{l}1 \\
7 \\
4\end{array}$ & $\begin{array}{l}4 \\
0 \\
0\end{array}$ & $\begin{array}{l}8 \\
6\end{array}$ & $\begin{array}{l}3 \\
4\end{array}$ & 21 & 781 & $\begin{array}{l}48.8 \\
1\end{array}$ & 4 \\
\hline Very less customers & $\begin{array}{l}4 \\
6 \\
8\end{array}$ & $\begin{array}{l}5 \\
9 \\
4\end{array}$ & $\begin{array}{l}5 \\
8\end{array}$ & 0 & 0 & 0 & 0 & $\begin{array}{l}112 \\
0\end{array}$ & 70 & 1 \\
\hline
\end{tabular}




\begin{tabular}{|l|l|l|l|l|l|l|l|l|l|l|l|}
\hline Strict norms are there by regulating authority & 0 & 0 & 0 & 5 & 1 & 1 & 147 & 496 & 31 \\
& & & & 0 & 2 & 7 \\
9 & 0 & & \\
\hline High cost incurred on the safety of property \& & 0 & 0 & 2 & 1 & 2 & 6 & 42 & 700 & 43.7 & 5 \\
employees & & & 3 & 0 & 5 & 8 & & & 5 \\
\end{tabular}

Table 3 illustrates the Garrett ranking of variables which are responsible for escalating the cost of penetration of insurance services to unreached areas in the study state. The 'very less customers' has Garrett rank first which indicates the responsible factor for escalating the cost of insurance penetration in unreached area of the state. So, large number of customer who is willing to participate or purchase the insurance services or products is very necessity. The second most dependable factor is the 'cost of one-time payment for the branch premises'. The next rank goes to the 'cost of fixed asset, furniture' and then 'the cost of employment of staff'. But the factor 'regulating authority strict norms' has the least rank among the seven factors. It means that the insurance strict norms by regulating authorities were not the very much significant factor which may increase the cost of penetration. Therefore, it is concluded that the major problem was lack of customer awareness, interest to insurance and high recurring cost. The higher officials are more willing to expand their branches to many areas.

\section{Conclusion:-}

From the above study, it's come to know that if the insurance company wants to expand and sustain their services, they need to attract large volume of customer by their innovative policies as the number of customer are very less in the state. And the second prerequisite step is to improve the social and economic condition of the state. However, the service providers see the population size of the area, their quantum of business and their safeness before opening a new branch in any area in the state.

\section{References:-}

1. Cummins, D. J., \& Doherty, N. A. (2006). The Economics of Insurance Intermediaries. The Journal of Risk and Insurance, 73(3), 359-396.

2. Kaur, J. (2015). Insurance Penetration and Density in India. International Journal of Business Management, ISSN, (2349-3402).

3. Kumabam, R. S., Meitei, C. I., Singh, S. S., \& Singh, K. B. (2013). Customer Perception of Health Insurance (HI) Products: A Study in Imphal City, Manipur (India). International Journal of Management. Vol. 4, Issue 3, $82-95$.

4. Marc, S. (2005). Micro insurance Workshop, ILO/STEP, October, Hyderabad.

5. Mukherjee, P. (August, 2010). Trends of Micro insurance in India. Micro Save India Focus Note 49.

6. Mukherjee, P. (February, 2012). Micro insurance product types in India. Micro Save India Focus Note 86.

7. Purusothaman, U. R. (2013). A case study on growth of investment in life insurance in India. TRANS Asian Journal of Marketing \& Management Research, 2(7), 26-36.

8. Ranade, A., \& Ahuja, R. (1999). Life insurance in India: Emerging issues. Economic and Political Weekly, 203212.

9. UNDP (2007). Building Security for the Poor Potential and Prospects for Micro Insurance. Human Development Report Unit, UNDP Regional Centre, Colombo. 